\title{
PRODUCTION OF NEGATIVE HEAVY ION BEAMS BY CHARGE EXCHANGE IN METAL VAPOUR
}

\author{
J. HEINEMEIER and P. TYKESSON
}

Institute of Physics, University of Aarhus, 80000 Aarhus C, Denmark

\begin{abstract}
Résumé. - On décrit une investigation systématique de l'échange de charge dans les vapeurs de $\mathrm{Na}$ et de $\mathrm{Mg}$ en vue de la production et de l'accélération de faisceau d'ions lourds négatifs dans un accélérateur tandem. Des intensités de l'ordre du $\mu \mathrm{A}$ à $20 \mathrm{keV}$ ont été obtenues au banc d'essai pour $\mathrm{Li}^{-}, \mathrm{Be}^{-}$, $\mathrm{B}^{-}, \mathrm{C}^{-}, \mathrm{O}^{-}, \mathrm{Na}^{-}, \mathrm{Al}^{-}, \mathrm{Si}^{-}, \mathrm{Cl}^{-}, \mathrm{Ca}^{-}, \mathrm{Fe}^{-}$, et $\mathrm{Au}^{-}$et ceci par l'échange de charge dans des vapeurs de $\mathrm{Na}$, $\mathrm{Mg}$ ou $\mathrm{K}$, subit par des ions positifs extraits de sources d'ions universelle et standard. Les valeurs mesurées pour l'émittance sont faibles comparées à celles obtenues avec les sources ions négatifs universelles existantes. Les faisceaux de $\mathrm{Li}^{-}, \mathrm{Be}^{-}, \mathrm{B}^{-}$et $\mathrm{Fe}^{-}$avec des intensités de l'ordre du $\mu \mathrm{A}$ ont été injectés et accélérés avec une bonne transmission dans notre accélérateur Tandem ÉN.
\end{abstract}

\begin{abstract}
The results of a systematic investigation of charge exchange in $\mathrm{Na}$ or $\mathrm{Mg}$ vapours are described together with applications to the production and acceleration of negative heavy ion beams in a tandem accelerator. $\mu \mathrm{A}$ intensities of $20 \mathrm{keV}$ beams of $\mathrm{Li}^{-}, \mathrm{Be}^{-}, \mathrm{B}-\mathrm{C}^{-}, \mathrm{O}^{-}, \mathrm{Na}^{-}, \mathrm{Al}^{-}, \mathrm{Si}^{-}, \mathrm{Cl}^{-}, \mathrm{Ca}^{-}$, $\mathrm{Fe}^{-}$, and $\mathrm{Au}^{-}$have been obtained on test bench by charge exchange in $\mathrm{Na}, \mathrm{Mg}$, or $\mathrm{K}$ vapour of positive beams extracted from standard, universal ion sources. The measured emittance values of these beams are low compared to existing, universal negative sources. $\mu \mathrm{A}$ beams of $\mathrm{Li}^{-}, \mathrm{Be}^{-}, \mathrm{B}^{-}$, and $\mathrm{Fe}^{-}$have been injected and accelerated with good transmission in our EN tandem accelerator.
\end{abstract}

1. Introduction. - In a recent, systematic investigation $[1,2]$ of equilibrium charge-state distributions for $10-90 \mathrm{keV}$ heavy-ion beams in charge exchange with $\mathrm{Na}$ and $\mathrm{Mg}$ vapours, we found that the negative fractions are generally so high $(1-90 \%)$ that negative elemental ion beams of a majority of the elements can be produced in $\mu \mathrm{A}$ intensities by charge exchange of positive ion beams from standard, universal isotope-separator sources. We found that this is the case even for a number of negative ions $\left(\mathrm{Li}^{-}, \mathrm{Be}^{-}, \mathrm{B}^{-}, \mathrm{Na}^{-}\right.$, $\mathrm{Al}^{-}, \mathrm{Ca}^{-}$and $\mathrm{Fe}^{-}$), which have proved difficult to obtain with other techniques due to low electron affinity, low sputtering yield or due to the negative state being metastable. One noteable exception is the $\mathrm{Mg}^{-}$ion, which we have not yet observed with certainty. In the practical tests of charge-exchange technique reported in the last part of this paper, we have concentrated mainly on producing ions of the difficult species mentioned above, thereby extending previously published [3] results for $\mathrm{Be}^{-}$and $\mathrm{B}^{-}$.

2. Charge Exchange. - The negative equilibrium fractions $F_{-1 \infty}$, reported in reference [2], for various $10-90 \mathrm{keV}^{-1 \omega}$ projectiles after passage through a $\mathrm{Na}$ target are shown in figure 1 . The projectile electron affinity is given in brackets. The negative yields show maxima in an energy region suitable for charge exchange in tandem injectors, except for the elements with particularly high fractions. The maximum nega-

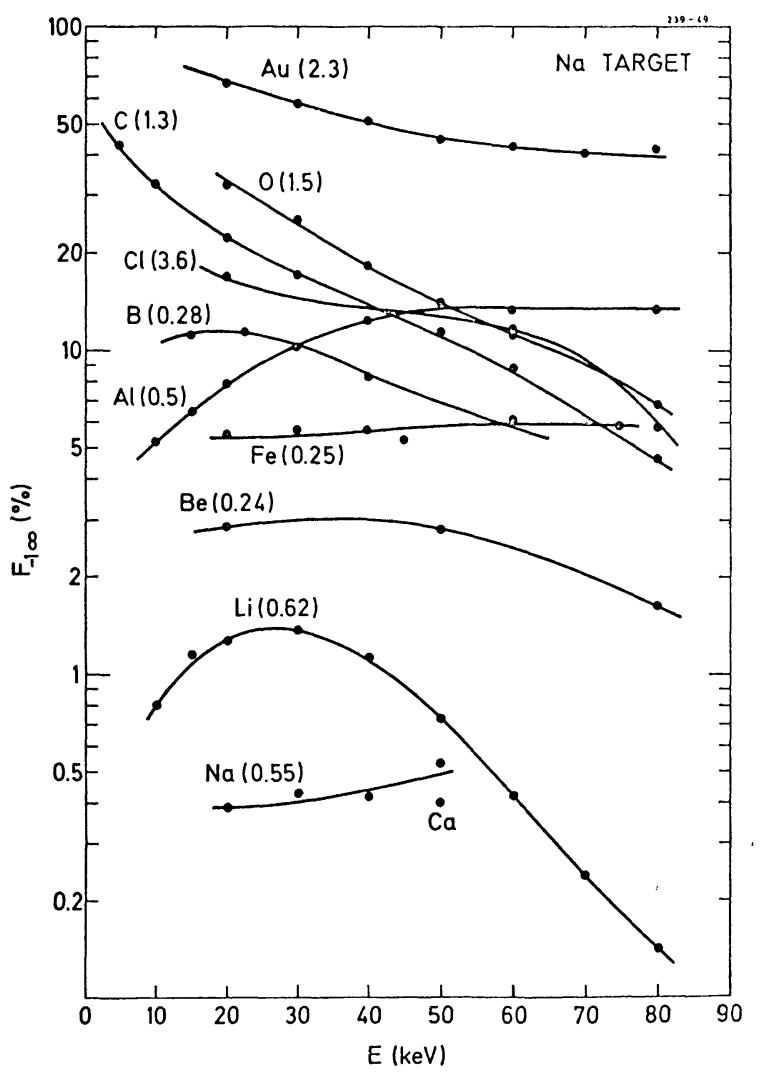

FIG. 1. - Negative equilibrium fractions in $\mathrm{Na}$, taken from reference [2]. The projectile electron affinity $(\mathrm{eV})$ is given in brackets. 
tive fractions exhibit a nearly systematic increase with projectile electron affinity, thus allowing extrapolation to elements outside the investigated range. The negative fractions in a $\mathrm{Mg}$ target [1] show a similar dependence. They are, however, generally smaller than in $\mathrm{Na}$ except for some projectiles $(\mathrm{O}, \mathrm{Cl})$ of high electron affinity. As discussed in reference [1], higher projectile electron affinity and lower target ionization potential both lead to higher maximum $F_{-1 \infty}$ values occuring at lower velocities.

The results for $\mathrm{Be}^{-}$and $\mathrm{Ca}^{-}$ions, produced in $\mathrm{Na}$ are encouraging (Fig. 1). Like the $\mathrm{Mg}^{-}$ion, these are thought to be metastable [4] and therefore difficult to produce [5]. It appears that charge exchange should be the ideal method for the two-step excitation process by which these ions are usually formed. For $\mathrm{Mg}^{-}$, however, we have been able to set an upper limit of $10^{-6}$ on $F_{-1 \infty}$ by directing a $150 \mu \mathrm{A}$ beam of 20 $\mathrm{keV} \mathrm{Mg}^{+}$through vapours of $\mathrm{Na}$ and $\mathrm{K}$ and it seems likely that no $\mathrm{Mg}^{-}$beam is produced at all. In contrast to this, Bethge et al. [6] claim a current of $300 \mathrm{nA} \mathrm{Mg}^{-}$ extracted from a Penning discharge. This is puzzling because otherwise it seems that negative ions such as $\mathrm{He}^{-}, \mathrm{Be}^{-}$and $\mathrm{Ca}^{-}$which are produced only in the low nA range by other techniques (sputtering, direct extraction), correspond to $F_{-1 \infty}$ values $>10^{-3}$ by charge exchange in $\mathrm{Na}$.

In reference [1], angular-scattering profiles of the charge-converted, fast ions were estimated on the basis of multiple-scattering experiments [7] and calculations $[8,9]$. In the relevant exchange-target thickness range, the width of the scattering profiles was found to be only weakly dependent on projectile (or target) atomic number, increasing by a factor of 2 from $\mathrm{Li}$ to $\mathrm{Au}$. This result is important since it means that the charge-exchange technique is nearly equally suited for light and heavy ion beams. The dependence on target thickness $\mu$ is strong $\left(\propto \mu^{2.5}\right)$ and the equilibrium target thickness (typically $\sim 2 \times 10^{15}$ atoms $/ \mathrm{cm}^{2}$ ) listed for different projectiles in references [1] and [2] is therefore an important parameter for the quality of the negative beam. The scattering distribution can be characterized by the half angle of a cone, symmetric about the direction of incidence, into which $50{ }^{\circ}{ }_{0}$ of an initially well collimated beam is scattered. The estimated $\propto$ value associated with scattering on the $\mathrm{Na}$ or $\mathrm{Mg}$ targets at equilibrium is $<3 \mathrm{mrad}$ for most of the beams at $20 \mathrm{keV}$. Exceptions are the $\mathrm{O}^{-}$and $\mathrm{Cl}^{-}$ beams which due to their large target thicknesses $\left(\sim 7 \times 10^{15}\right.$ atoms $\left./ \mathrm{cm}^{2}\right)$ have estimated $\alpha$ values of the order of $50 \mathrm{mrad}$, but it is worth noting that in reference [1] it was observed that the projectiles with high negative yields generally require large target thicknesses for equilibrium.

In the following we report on the practical application of the above investigations to the production of negative ion beams for tandem accelerators. Tests were carried out on the ion-source test bench as well as on the Aarhus EN tandem accelerator. Design considerations for the metal-vapour cell used in the test are also described in the following.

3. Charge-exchange cell. - The metal-vapour charge exchange cell was designed with particular consideration to (i) low thermal time constants (low mass, good thermal contact between heating element and cell). (ii) The cell is divided into two thermally separated units, a target chamber of high temperature and a reservoir of somewhat lower temperature which determines the vapour pressure. The temperatures should be uniform within each region. (iii) In particular, regions near the beam axis (e.g., cell apertures) should not be colder than the reservoir.

Details of the exchange cell are shown in figure 2.

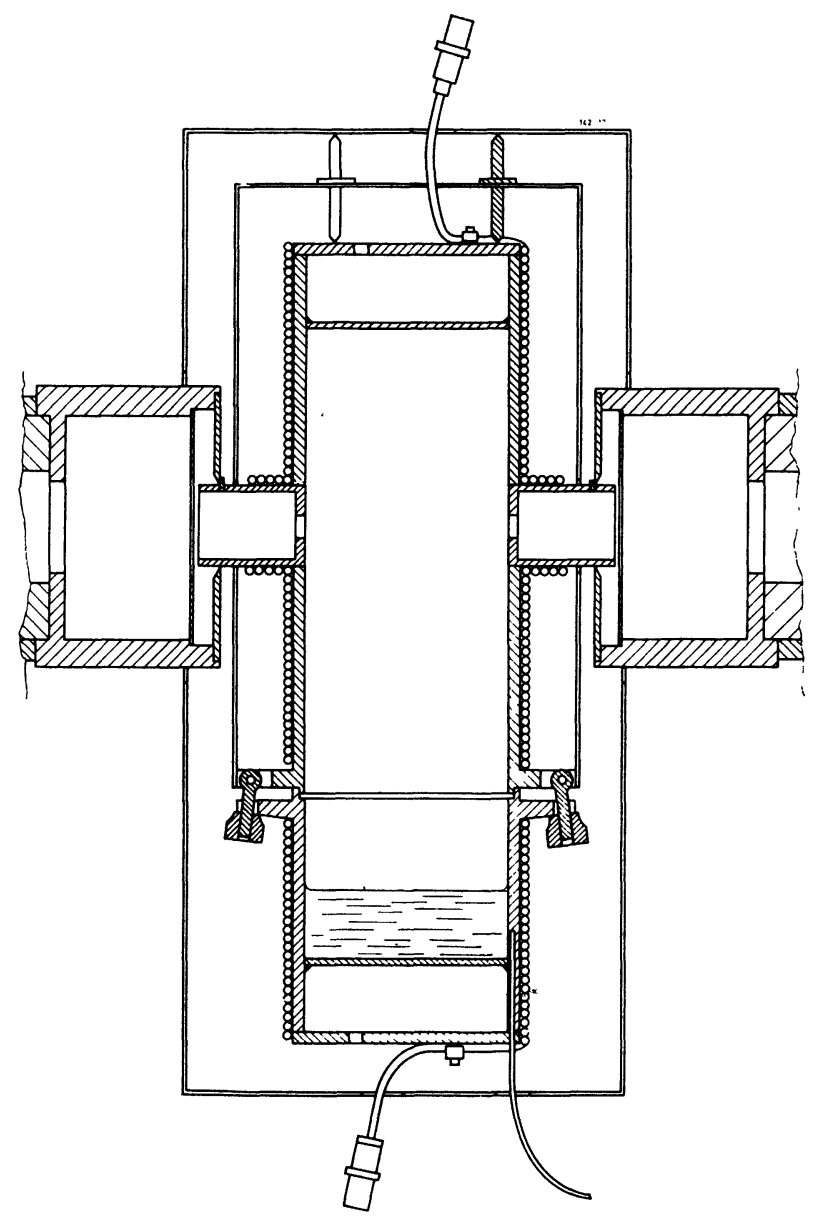

FIG. 2. - Metal vapour charge-exchange cell.

The target chamber and the reservoir are made of stainless steel to avoid chemical attack by the charge material. The wall thickness is only $2 \mathrm{~mm}$, but a uniform temperature distribution is achieved by two means : Firstly, the top and bottom of the cell are placed $15 \mathrm{~mm}$ from the cylinder end plates, which then act as heat shields with elevated temperature. Secondly, the cell is uniformly heated by Philips thermocoax (1.5 $\mathrm{mm}$ diameter), closely wound over the full length of the cylinder, including also the entrance and exit tubes on the target chamber. Ceramic paste was used 
to provide thermal contact with the heating element. The cell is placed between two water cooled condensors and supported at each end by the knife-edged aperture in a thin, stainless steel disc. This arrangement minimizes the thermal contact to the condensors so as to avoid blocking of the beam passage with charge material due to low temperature at the cell entrance and exit. The shape of the condensors ensures that most of the evaporated charge material is condensed at a safe distance from the beam axis. The heat shield around the target chamber ensures a $\sim 30 \%$ higher temperature of this part of the cell compared to the reservoir. When operation at temperatures above $400{ }^{\circ} \mathrm{C}$ is required ( $\mathrm{Li}$ and $\mathrm{Mg}$ targets), the assembly is enclosed in an additional heat shield. The temperature of the charge material is monitored with a thermocouple mounted in a $20 \mathrm{~mm}$ deep bore in the wall of the reservoir. An automatic temperature control is used, and with $170 \mathrm{~W}$ input power, a sodium working temperature of $300{ }^{\circ} \mathrm{C}$ is reached in $\sim 15 \mathrm{~min}$. with an overshoot of less than $5^{\circ} \mathrm{C}$ and subsequently kept constant within $1^{\circ} \mathrm{C}$. The thermal time constant of the system is characterized by the cooling rate with power off. At $300^{\circ} \mathrm{C}$ the cooling rate is $10^{\circ} \mathrm{C} / \mathrm{min}$., corresponding to a reduction in the $\mathrm{Na}$ pressure of $30 \% / \mathrm{min}$. This fast response greatly facilitates the vapour-pressure optimizing procedure. Furthermore the uniform reservoir temperature and the close thermal contact between thermocouple and the charge-exchange material ensures that no hysteresis effects are observed between charge-exchange efficiencies obtained with rapidly increasing and decreasing temperatures. The cell apertures are $4 \mathrm{~mm}$ diameter and $40 \mathrm{~mm}$ apart. This corresponds to a half acceptance angle of $100 \mathrm{mrad}$ and a two-dimensional elliptical phase-space acceptance of $44 \mathrm{~mm} . \operatorname{mrad} . \mathrm{MeV}^{1 / 2}$ at $20 \mathrm{keV}$, which is considerably higher than the emittance of the positive ion sources used. (Here and in the following we include a factor of $\pi$ in the emittance value as recommended by Larson and Jones [10].)

4. Test-bench measurements. - In table I, the charge-exchange results on the test bench are recorded. Two different positive ion sources from Danfysik A/S were used. Type 910 is an universal separator source developed by Almén and Nielsen [11], and type 911A is a modified version of the Sidenius hollowcathode source [12]. Positive ions are extracted at $20 \mathrm{kV}$ and focussed to a waist in the exchange cell by means of an einzel lens, so positioned that the beamconvergence half-angle is $\sim 30 \mathrm{mrad}$. A second lens matches the beam to the $60^{\circ}$ double-focussing analyzing magnet. The intensity of the momentum-analyzed beam is measured with a Faraday cup after the object slit. When the cup is retracted, the beam is

\section{TABLE I}

Charge-exchange results obtained on the test bench for different negative ion beams. $F_{-1 \infty}$ is the equilibrium fraction at $20 \mathrm{keV}$ and $\mu_{\infty}$ is the equilibrium exchange target thickness both taken from references [1] and [2]. $\alpha$ is the maximum scattering angle of $50 \%$ of the beam

\begin{tabular}{|c|c|c|c|c|c|c|c|c|c|c|c|}
\hline Ion & $\begin{array}{l}\text { Electron } \\
\text { affinity } \\
(\mathrm{eV})\end{array}$ & $\begin{array}{l}\text { Charge } \\
\text { exchange } \\
\text { material }\end{array}$ & $\begin{array}{c}\text { Ion } \\
\text { source }\end{array}$ & $\begin{array}{c}\text { Positive } \\
\text { Beam } \\
(\mu \mathrm{A})\end{array}$ & $\begin{array}{c}\text { Negative } \\
\text { Beam } \\
(\mu \mathrm{A})\end{array}$ & $\begin{array}{c}\text { Conversion } \\
\text { efficiency } \\
(\%)\end{array}$ & $\begin{array}{l}F_{-1 \infty} \\
(\%)\end{array}$ & $\begin{array}{c}\text { Emittance }(*) \\
\text { positiv } \\
\text { Beam } \\
\text { mm mrad } \mathrm{MeV}^{1 / 2}\end{array}$ & $\begin{array}{c}\text { Emittance }\left(^{*}\right) \\
\text { negativ } \\
\text { Beam } \\
\text { mm mrad } \mathrm{MeV}^{1 / 2}\end{array}$ & $\begin{array}{c}\mu_{\infty} \\
10^{15} \\
\text { atoms } / \mathrm{cm}^{2}\end{array}$ & $\begin{array}{c}\alpha(50 \%) \\
\operatorname{mrad}\end{array}$ \\
\hline - & - & - & 一 & - & - & - & - & - & - & - & - \\
\hline \multirow[t]{4}{*}{${ }^{7} \mathrm{Li}^{-}$} & 0.62 & $\mathrm{Na}$ & $911 \mathrm{~A}$ & 170 & 2.0 & 1.2 & 1.3 & & & 0.8 & 0.1 \\
\hline & & $\mathrm{Na}$ & 910 & 130 & 1.6 & 1.2 & 1.3 & 4.3 & 5.0 & 0.8 & 0.1 \\
\hline & & $\mathbf{K}$ & $911 \mathrm{~A}$ & 180 & 2.5 & 1.4 & & & & & \\
\hline & & $\mathrm{K}$ & 910 & 70 & 1.0 & 1.4 & & 10.4 & 6.0 & & \\
\hline${ }^{9} \mathrm{Be}^{-}$ & +0.24 & $\mathrm{Na}$ & $911 \mathrm{~A}$ & 125 & 3.4 & 2.7 & 2.8 & & & 3.2 & 4 \\
\hline \multirow[t]{2}{*}{${ }^{11} \mathrm{~B}^{-}$} & 0.28 & $\mathrm{Mg}$ & $911 \mathrm{~A}$ & 50 & 3.0 & 6.0 & 7.0 & & & 0.8 & 0.2 \\
\hline & & $\mathrm{Na}$ & $911 \mathrm{~A}$ & 30 & 2.8 & 9.3 & 11.5 & & & 1.2 & 0.4 \\
\hline \multirow[t]{2}{*}{${ }^{12} \mathrm{C}^{-}$} & 1.3 & Mg & 910 & 24 & 3.2 & 13.3 & 14.4 & & & 1.5 & 1 \\
\hline & & $\mathrm{Na}$ & 910 & 28 & 4.5 & 16.1 & 22.0 & 8.2 & 6.9 & 1.5 & 1 \\
\hline \multirow[t]{2}{*}{$160^{-}$} & 1.46 & $\mathbf{M g}$ & 910 & 16 & 3.0 & 18.7 & 40.0 & & & 7.5 & 60 \\
\hline & & $\mathrm{Na}$ & 910 & 14 & 2.3 & 16.4 & 33.0 & 5.3 & 8.8 & & \\
\hline${ }^{23} \mathrm{Na}^{-}$ & 0.54 & $\mathrm{Na}$ & $911 \mathrm{~A}$ & 110 & 0.4 & 0.36 & 0.4 & & & & \\
\hline \multirow[t]{2}{*}{${ }^{24} \mathrm{Mg}^{-}$} & +0.32 & $\mathrm{Na}$ & 910 & 120 & $\leq 10^{-4}$ & $\leq 10^{-6}$ & & & & & \\
\hline & & $\mathrm{K}$ & 910 & 150 & $\leq 10^{-4}$ & $\leq 10^{-6}$ & & & & & \\
\hline \multirow[t]{2}{*}{${ }^{27} \mathrm{Al}^{-}$} & 0.46 & $\mathrm{Na}$ & 910 & 25 & 1.1 & 4.4 & 7.8 & 8.5 & 6.6 & 0.6 & 0.1 \\
\hline & & $\mathrm{K}$ & 910 & 10 & 0.6 & 6.0 & & 10.5 & 7.8 & & \\
\hline \multirow[t]{2}{*}{$28 \mathrm{Si}^{-}$} & 1.39 & $\mathrm{Na}$ & 911A & 65 & 15.5 & 23.8 & & & & & \\
\hline & & $\mathrm{Na}$ & 910 & 13 & 3.2 & 25.0 & & 6.6 & 6.6 & & \\
\hline${ }^{35} \mathrm{Cl}^{-}$ & 3.6 & $\mathrm{Mg}$ & 910 & 15 & 7.0 & 47.0 & 77.0 & & & 7.5 & 70 \\
\hline \multirow[t]{2}{*}{${ }^{40} \mathrm{Ca}^{-}$} & unknown & $\mathrm{Na}$ & $911 \mathrm{~A}$ & 100 & 0.5 & 0.5 & & & & & \\
\hline & & $\mathbf{K}$ & $911 \mathrm{~A}$ & 40 & 0.5 & 1.2 & & & & & \\
\hline $56 \mathrm{Fe}^{-}$ & 0.25 & $\mathrm{Na}$ & 910 & 30 & 0.7 & 2.3 & 5.5 & 11.6 & 5.7 & 0.8 & 0.3 \\
\hline${ }^{197} \mathrm{Au}^{-}$ & 2.3 & $\mathrm{Na}$ & $911 \mathrm{~A}$ & 29 & 10.0 & 34.5 & 68 & & & 3.0 & 8 \\
\hline
\end{tabular}

(+) Metastable.

(*) A factor of $\pi$ is included in the emittances values. 
passed into an emittance-measuring equipment, and the beam emittance may be determined in the $x$ - and $y$-plane.

In the test runs, we first adjusted ion-source and lens parameters to give maximum, analyzed, positive beam current; then the exchange cell was heated and its temperature adjusted to give maximum negative beam. The measured currents and the corresponding charge-conversion efficiencies are shown in table $I$. Tests were made with charge-exchange targets $\mathrm{Na}$, $\mathrm{Mg}$ and $\mathrm{K}$ and the equilibrium fractions $F_{-1 \infty}$ at $20 \mathrm{keV}$ from references [1] and [2] (Fig. 1) are included in the table where available. Also listed are equilibrium target thickness values $\mu_{\infty}$ taken from references [1] and [2] and the maximum scattering angle $\alpha$ for $50 \%$ of the beam, estimated as described in reference [1]. With the exception of $\mathrm{Al}$ and $\mathrm{Fe}$, the chargeconversion efficiencies obtained on the test bench are in good agreement with $F_{-1 \infty}(20 \mathrm{keV})$ as long as they are low, whereas an increasing disagreement is found at larger values. This is explained by the magnet-pole gap limiting negative beams of large angular divergences, i.e., beams which are scattered strongly on the exchange target. Generally, scattering effects are more severe for projectiles with large $F_{-1 \infty}$ values because they require higher target thicknesses for equilibrium (see Ref. 1). The $\mathrm{Al}^{+}$and $\mathrm{Fe}^{+}$beams were produced by the $\mathrm{CCl}_{4}$ method, and a low transmission due to space-charge effects from the strong chlorine component in the extracted and the charge-converted beam may explain the low conversion efficiencies observed for $\mathrm{Al}$ and $\mathrm{Fe}$. We note from table I that comparatively large negative beam currents have been obtained for elements of low electron affinity because their low charge conversion efficiencies are compensated by particularly large positive currents extracted from the sources. Emittance measurements were made for positive as well as for negative ion beams. Due to space-charge compensation at the beam waist in the charge-exchange cell, lower emittances were generally found for the negative beams than for the positive ones. With the emittance defined as the area enclosed by the $10 \%$ brightness contour in the two-dimensional emittance diagramme, the negative-ion-beam emittance was found to vary from 5 to $9 \mathrm{~mm}$.mrad.$\mathrm{MeV}^{1 / 2}$ for the measured beams, depending on the type of beam and ion-source parameters.
5. Tandem tests. - Because of their special interest, beams of charge converted $\mathrm{Li}, \mathrm{Be}, \mathrm{B}$ and $\mathrm{Fe}$ were selected for testing on the tandem. The negative-ion beams were produced by charge exchange in $\mathrm{Na}$ and with the same ion source-, lens- and cell-geometry as that on the test bench: A Danfysik 911A was used for the production of the positive ion beam for $\mathrm{Be}$ and $\mathrm{B}$, while a Danfysik 910 was used for $\mathrm{Li}$ and $\mathrm{Fe}$. The negative ions were accelerated to 90 or $130 \mathrm{keV}$ prior to injection into the tandem. The lay-out of the injector is described in reference [13].

The analyzed high-energy beams energing from the tandem in different charge states, listed in table II, were recorded at a terminal voltage of $5 \mathrm{MV}$ with 5$10 \mu \mathrm{g} / \mathrm{cm}^{2}$ carbon foils in the terminal stripper (gas stripper for $\mathrm{Fe}$ ). With the listed injected negative ion beams, the analyzed positive ion beams correspond to a total transmission of $50 \%$ except for $\mathrm{Li}$, where the figure is $35 \%$, which is presumeably due to improper adjustment of the injector. The injected beam corrents are close to those achieved on the test bench and we therefore expect that the remaining negative beams listed in table I may be accelerated with similar transmission.

6. Conclusion. - The reported measurements have shown that, apart from being very universal, the charge-exchange method is particularly suited for the production of beams of elemental negative ions with low binding energy, regardless of their mass. For such ions, we have obtained absolute beam currents, generally in excess of those achieved with the best of the existing sources $[14,16]$. That fact that the measured emittances are a factor of 3-4 lower than those for other sources $[14,15]$ is important since the emittances of the latter are of the order of typical acceptance values for tandem accelerators. The present emittance values are mainly determined by the positive ion source rather than by scattering effects in the charge-exchange process. On the background of the results reported here and in references [1] and [2], it should be possible to give a realistic estimate of achieveable negative beam currents from available positive beam currents of elements not included in the present investigation. It should be noted here that standard, universal positive sources have been used so that the

TABLE II

Analyzed beam currents for different charge states obtained on the tandem accelerator at a terminal voltage of $5 \mathrm{MV}$. The injected negative ion beams were produced by charge exchange $i \mathrm{Na}$.

\begin{tabular}{|c|c|c|c|c|c|c|c|c|}
\hline \multirow[b]{2}{*}{ Beam } & \multirow[b]{2}{*}{$\begin{array}{l}\text { Positive } \\
\text { Ion source }\end{array}$} & \multirow{2}{*}{$\begin{array}{l}\text { Injected } \\
\text { neg. beam } \\
(\mu \mathrm{A})\end{array}$} & \multirow{2}{*}{$\begin{array}{c}\text { Injection } \\
\text { Energy } \\
(\mathrm{keV})\end{array}$} & \multicolumn{5}{|c|}{ Analyzed Beams $(\mu \mathrm{A})$} \\
\hline & & & & +2 & +3 & +4 & +5 & +6 \\
\hline - & - & - & - & - & - & - & - & - \\
\hline $\mathrm{Li}$ & 910 & 1.3 & 90 & 0.14 & 1.14 & & & \\
\hline $\mathrm{Be}$ & 911A & 2.3 & 130 & 0.23 & 2.04 & 2.30 & & \\
\hline B & 911A & 3.0 & 130 & 0.09 & 1.77 & 2.56 & 0.58 & \\
\hline $\mathrm{Fe}$ & 910 & 0.4 & 90 & 0.05 & 0.18 & 0.26 & 0.18 & 0.11 \\
\hline
\end{tabular}


present results could clearly be further improved by choosing ion sources optimized for the particular ion in question. Thus, for example, Clampitt et al. [17] has developed a compact, positive source for highintensity metal-ion beams. As regards the choice of exchange target, Na vapour appears to be suitable for a wide range of ions. For heavy ions with low electron affinity, slightly higher negative yields may be found in the $20-\mathrm{keV}$ region, using $\mathrm{K}$ or even heavier alkalis.

Acknowledgements. - Our sincere thanks are due to E. Jans for his skilfull assistance in the practical development work. The work was financially supported by The Danish State Research Foundation.

\section{References}

[1] Heinemeier J. and Hvelplund P.., (submitted for publication in Nucl. Instrum. Methods).

[2] Heinemeier J. and Hvelplund P., (to be published).

[3] Heinemeier J. and Tykesson P., Nucl. Instrum. Methods 141 (1977) 183.

[4] LiNeberger W. C., IEEE Trans. Nucl. Sci. NS-23 (1976) 934, and Hotop H. and Lineberger W. C., J. Phys. Chem. Ref. Data 4 (1975) 539.

[5] Middleton R., Nucl. Instrum. Methods 141 (1977) 373.

[6] Bethge K., Heinicke E. and Bauman H., Phys. Lett. 23 (1966) 542.

[7] Knudsen H., Besenbacher F., Heinemeier J. and HvelPLund P., Phys. Rev. A 13 (1976) 2095.

[8] Sigmund P. and Winterbon K. B., Nucl. Instrum. Methods 119 (1974) 541.

[9] Marwick A. D. and Sigmund P., Nucl. Instrum. Methods 126 (1975) 317.
[10] LaRson J. D. and Jones C. M., Nucl. Instrum. Methods 140 (1977) 489.

[11] Almén O. and Nielsen K. O., Nucl. Instrum. Methods 1 (1957) 302.

[12] Sidenius G., in Proc. Conf. on Electromagnetic isotope separators and the techniques of their applications, (Marburg) (1970) 423.

[13] Andersen H. H. and Tykesson P., IEEE Trans. Nucl. Sci. NS-22 (1975) 1632.

[14] Middleton R., (to be published in Nucl. Instrum Mcthods).

[15] Braun-Elwert G., Huber J., Korschinek G. and KutsCHERA W., Contribution to the Conference on the Physics of the Tandem (1976) Trieste and Padova, Italy. To be published in Nucl. Instrum. Methods.

[16] Tykesson P., Andersen H. H. and Heinemeier J., IEEE Trans. Nucl. Sci. NS-23 (1976) 1104.

[17] Clampitt R., Aitken K. L. and Jefferies D. K., J. Vac. Sci. Technol. 12 (1975) 1208. 